\title{
Assessment of physicochemical and microbial properties of soil of a disturbed forest in Ondo state, Nigeria
}

\author{
E. T. Adedeji, K. Jayeola, A. S. Akinbowale* and M. S. Tolorunju \\ Department of Forestry and Wood Technology, Federal University of Technology, Akure, Nigeria \\ *Corresponding Author: akinbowaleas@futa.edu.ng
}

\begin{abstract}
Deforestation and degradation greatly affect the population of soil microbes and reduces the quality of the soil. This study was carried out to assess the physiochemical and microbial properties of soil of a disturbed forest in Ondo state, Nigeria. Data collection took place in Osse River Park. Two parallel line transects of $200 \mathrm{~m}$ apart were laid and two equal sample plots $(50 \mathrm{~m} \times 50$ $\mathrm{m})$ were laid in alternate direction of each transect. The sample plots laid in the disturbed forest was used for soil collection. Soil samples were collected at three depths $(0-15 \mathrm{~cm}, 15-30 \mathrm{~cm}$ and $30-45 \mathrm{~cm})$ along the diagonal for each of the sample plot with the aid of soil auger. The standard procedure for determining the total number of soil microbes was adopted for bacteria and fungi culturing. The results obtained in this study revealed that sand content, organic matter, organic carbon, calcium, phosphorous and nitrogen reduces significantly as the depth increases. Mean values for sand ranged from 66.6-77.1 and the silt content ranged from 5.94 to 8.2. Clay, silt and magnesium were higher in depth 30-45 cm than any other depths. At different depth, significant difference was observed in the organic matter. Soil $\mathrm{pH}$, magnesium, potassium, calcium and sodium were not significantly different within the soil depths. Irrespective of the depth, soil pH ranged from 5.69-6.66 which shows that the soil is slightly acidic. A total number of eight fungi and nine bacteria were isolated in the study area. Negative and positive correlations were found in the soil properties when the level of relationship was tested. This study concluded that deforestation affects soil quality and microbial diversity. Degraded forests should be protected and should be allowed to recuperate and the remaining forests should be protected from further anthropogenic activities.
\end{abstract}

Keywords: Deforestation, Disturbed forest, Soil physicochemistry, Soil microbes, Soil quality.

\section{INTRODUCTION}

Soil is a complex and dynamic ecosystem where substantial physical, chemical, and biological processes take place (Jelena et al., 2018). According to Nannipieri et al. (2003), the most important biological processes in soil (80-90\%) occur due to microbial enzyme systems reactions. Rousk et al. (2008) stated that soil chemical and physical characteristics are major factors of soil microbial community structure. The physicochemical properties of soil are ultimately related to soil fertility which intends affect the floristic composition of forest. There is a mutual connection between the soil microflora and the vegetation of an ecosystem. Microorganisms help in mineralization and decomposition of plant materials to a form that can be absorbable by plants (Pietikainen, 1999). Sigstad et al. (2002) also pin pointed that bacterium as the most occurrence and it is through their metabolic activity that minerals and soil organic matter are transformed in a way that important nutrients such as $\mathrm{N}, \mathrm{P}$, and $\mathrm{S}$ are simultaneously converted into assimilable forms for plant and other micro-organisms.

Deforestation, the dynamic process whereby continuous forest is divided into small isolated patches, is a pervasive problem for plants and soil properties (Haddad et al., 2015). The conversion of forests to agriculture or other land uses is associated with a decrease in soil fertility which form a basis for index to assess soil fertility is its physicochemical and microbial activity. Most tropical rainforest soils are relatively poor in nutrients. The plant species diversity affects microbial process, which controls the rate of Nitrogen cycling in the ecosystem (Adekunle et al., 2011).

In respect to this, little is known on the status of physicochemical and microbial properties of Osse river park, Ondo State Nigeria presently a disturbed forest. The growth and population of soil microorganisms are of great importance and they can be influenced by chemical, physical and biological properties of the soil. The availability of macro and micro nutrient elements can limit microbial population growth in a particular soil ecosystem. Essential soil elements for plant growth, such as, nitrogen, phosphorus, potassium, sulphur and micro nutrients influences the microbial population as these nutrient elements are also needed for microbial growth and activity. In a healthy soil, there are and thousands of species of soil bacterial and fungi and many other. The multifaceted response of physicochemical and microbial diversity of soil in Osse River Park is poorly understood as few researches has been carried out in the area of knowledge. Thus, this research aimed at assessing the physicochemical and microbial status of the study area so as to establish improved management and strategies for forests conservation in South-western, Nigeria. 


\section{METHODOLOGY}

\section{Study area}

The research was carried out in disturbed forest of Osse River Park formerly known as Ifon forest reserve. It is located in Osse local government area of Ondo State, south western Nigeria. The park covers an area of about 282.35 $\mathrm{km}^{2}$ lying between Latitude $60^{\circ} 54^{\prime} \& 70^{\circ} 14^{\prime} \mathrm{N}$ and Longitude $50^{\circ} 43^{\prime} \& 50^{\circ} 54^{\prime}$ E. The Park is strategically located and is accessible from any part of Nigeria, about $20 \mathrm{~km}$ from Owo, $80 \mathrm{~km}$ from Akure, $6 \mathrm{~km}$ from Ifon and about $80 \mathrm{~km}$ from Benin City.

\section{Data collection}

Sampling technique for soil collection

The laying of the plot was carried out using the systematic line transects (Fig. 1). Two parallel transects of $200 \mathrm{~m}$ apart were laid after a 50 meter off set had been measured out. Thereafter, four sample plots of equal size $(50 \mathrm{~m} \times 50 \mathrm{~m})$ were alternately laid on each transect.

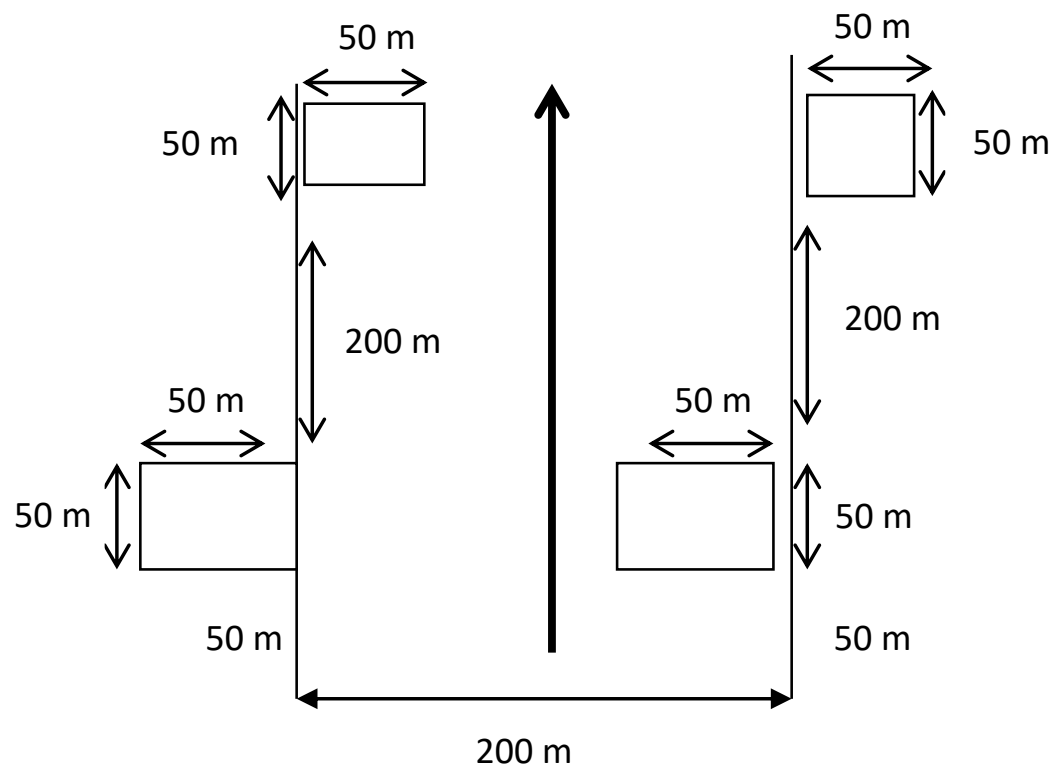

Figure 1. Systematic line transects.

\section{Soil properties}

The sample plots laid in the disturbed forest was used for soil collection. Soil samples were collected at three depths along the diagonal for each of the sample plot with the aid of soil auger. The soil samples were collected at different soil depth of 0-15 cm, 15-30 cm and 30-45 cm. All soil collected within the sample plot at a particular depth was bulked and mixed together. The bulked samples for each soil depth were air dried and sieved with a 2 mm sieve and taken to the laboratory for physiochemical and biological analysis.

\section{Data analyses}

\section{Physicochemical properties analysis}

Soil samples collected from each layer separately were air dried and sieved through $2 \mathrm{~mm}$ sieve. The selected soil physicochemical properties investigated were: Sand, silt, clay, calcium, magnesium, soil pH, phosphorus, potassium, nitrogen, Soil Organic carbon, Organic matter.

\section{Bacteria and Fungi isolation, identification and counting}

The standard procedure for determining the total number of soil microbes was adopted for bacteria and fungi culturing. Soil samples were suspended and prepared with sterile water and a serial dilution of five factors was done for correct counting. $1 \mathrm{ml}$ of the appropriate dilution was transferred to sterilized petri dishes containing sterile molten nutrients agar at about $37^{\circ} \mathrm{C}$. This was mixed and allowed to solidify. This was then incubated for 24 hrs. The bacteria that grow into colonies were sub-cultured for easy identification. This identification was done according to Berges's manual of determination bacteriology.

For fungi culturing, serial dilution of the suspension was transferred into petri dishes containing sterile Potato Dextrose Agar. This was kept in an incubator at $30^{\circ} \mathrm{C}$ for 5 days. Microscopic characterization was carried out for fungi and bacteria identification.

\section{Statistical analysis}

Statistical analysis was carried out on the data obtained. Bacteria and fungi population values were logarithmically 
transformed. Pearson rank correlation was used to determine the level of relationship in the soil properties.

\section{RESULTS}

Mean values for the soil physicochemical properties are presented in the table $1 \& 2$. The sand, organic matter, organic carbon, calcium Phosphorous and nitrogen content decreases as we go down the depths. Irrespective of the depths, mean values for sands ranged from 66.6-77.1 and the silt content ranged from 5.94 to 8.2. Clay, silt and magnesium were higher in depth 30-45 cm than any other depths. At different depth, significant difference was observed in the organic matter. Soil $\mathrm{pH}$, magnesium, potassium, calcium and sodium were not significantly different within the soil depths.

Table 1. Mean values for physical properties of the soil samples in the study area.

\begin{tabular}{lrrr}
\hline Soil Physical & \multicolumn{3}{c}{ Depths } \\
\cline { 2 - 4 } Properties & $\mathbf{0 - 1 5} \mathbf{~ c m}$ & $\mathbf{1 5 - 3 0} \mathbf{~ c m}$ & $\mathbf{3 0 - 4 5} \mathbf{~ c m}$ \\
\hline Sand (\%) & $77.1 \pm 1.16^{\mathrm{a}}$ & $70.1 \pm 2.01^{\mathrm{ab}}$ & $66.6 \pm 1.19^{\mathrm{b}}$ \\
Silt (\%) & $6.44 \pm 0.58^{\mathrm{ab}}$ & $5.94 \pm 2.5^{\mathrm{b}}$ & $8.2 \pm 1.26^{\mathrm{a}}$ \\
Clay (\%) & $16.46 \pm 0.61^{\mathrm{b}}$ & $23.96 \pm 0.62^{\mathrm{a}}$ & $25.2 \pm 0.5^{\mathrm{a}}$ \\
\hline
\end{tabular}

Table 2. Mean values for chemical properties of the soil samples in the study area.

\begin{tabular}{lrrr}
\hline Soil Chemical & \multicolumn{3}{c}{ Depths } \\
\cline { 2 - 4 } Properties & $\mathbf{0 - 1 5} \mathbf{~ c m}$ & $\mathbf{1 5 - 3 0} \mathbf{~ c m}$ & $\mathbf{3 0 - 4 5} \mathbf{~ c m}$ \\
\hline $\mathbf{O C}(\%)$ & $2.69 \pm 0.47^{\mathrm{a}}$ & $2.58 \pm 0.29^{\mathrm{a}}$ & $2.29 \pm 0.32^{\mathrm{ab}}$ \\
$\mathbf{O M}(\%)$ & $2.65 \pm 0.61^{\mathrm{a}}$ & $1.98 \pm 0.42^{\mathrm{b}}$ & $1.46 \pm 0.36^{\mathrm{c}}$ \\
$\mathbf{K}\left(\mathbf{m o l ~ k g} \mathbf{~ k}^{-\mathbf{1}}\right)$ & $0.23 \pm 0.01^{\mathrm{a}}$ & $0.13 \pm 0.04^{\mathrm{a}}$ & $0.14 \pm 0.03^{\mathrm{a}}$ \\
$\mathbf{N a}\left(\mathbf{m o l ~ k g}^{-\mathbf{1}}\right)$ & $0.21 \pm 0.03^{\mathrm{a}}$ & $0.2 \pm 0.02^{\mathrm{a}}$ & $0.21 \pm 0.04^{\mathrm{a}}$ \\
$\mathbf{C a}\left(\mathbf{m o l ~ k g}^{-1}\right)$ & $1.48 \pm 0.21^{\mathrm{a}}$ & $1.33 \pm 0.09^{\mathrm{a}}$ & $1.2 \pm 1.68^{\mathrm{a}}$ \\
$\mathbf{M g}\left(\mathbf{m o l ~ k g}^{-1}\right)$ & $0.78 \pm 0.25^{\mathrm{a}}$ & $0.78 \pm 0.17^{\mathrm{a}}$ & $0.8 \pm 0.35^{\mathrm{a}}$ \\
$\mathbf{P}\left(\mathbf{m g ~ k g}^{-1}\right)$ & $13.77 \pm 0.30^{\mathrm{a}}$ & $10.44 \pm 3.87^{\mathrm{a}}$ & $8.134 \pm 0.44^{\mathrm{b}}$ \\
$\mathbf{S o i l ~} \mathbf{~ p H}$ & $6.66 \pm 0.70^{\mathrm{a}}$ & $6.55 \pm 0.93^{\mathrm{a}}$ & $5.69 \pm 0.40^{\mathrm{a}}$ \\
$\mathbf{N}\left(\mathbf{m g ~ k g}^{-\mathbf{1}}\right)$ & $0.39 \pm 0.07^{\mathrm{a}}$ & $0.24 \pm 0.03^{\mathrm{a}}$ & $0.19 \pm 0.04^{\mathrm{b}}$ \\
\hline
\end{tabular}

Note: $\mathrm{OC}=$ Organic Carbon, $\mathrm{OM}=$ Organic matter, $\mathrm{K}=$ Pottassium, $\mathrm{Na}=$ Sodium, $\mathrm{Ca}=$ Calcium, $\mathrm{Mg}=$ Magnesium, $\mathrm{P}=$ Phosphorous.

The different species of fungi and bacteria that were isolated in the study area is presented in table $3 \& 4$. A total of eight fungi and nine bacteria were found in the study area.

Table 3. Occurrence of soil fungi in the study area.

\begin{tabular}{llr}
\hline S.N. & Species & Occurrence \\
\hline $\mathbf{1}$ & Alternaria alternata (Fr.) Keissl. & $\mathrm{V}$ \\
$\mathbf{2}$ & Aspergillus fumigatus Fresenius & $\mathrm{V}$ \\
$\mathbf{3}$ & Aspergillus niger van Tieghem & $\mathrm{V}$ \\
$\mathbf{4}$ & Rhizopus stolonifer Vuillemin & $\mathrm{V}$ \\
$\mathbf{5}$ & Saccharomyces cerevisiae Meyen ex E.C. Hansen & $\mathrm{V}$ \\
$\mathbf{6}$ & Trichoderma viride Pers. & $\mathrm{V}$ \\
$\mathbf{7}$ & Fusarium merismoides Corda & $\mathrm{V}$ \\
$\mathbf{8}$ & Candida albicans (C.-P. Robin) Berkhout & $\mathrm{V}$ \\
\hline & & Total \\
\hline
\end{tabular}

Note: $V=$ Present

Table 4. Occurrence of soil bacteria in the study area.

\begin{tabular}{|c|c|c|}
\hline S.N. & Species & Occurrence \\
\hline 1 & Azotobacter agilis J. Bacteriol & $\mathrm{V}$ \\
\hline 2 & Azotobacter orleanen & $\mathrm{V}$ \\
\hline 3 & Bacillus alvei Cheshire \& Cheyne & $\mathrm{V}$ \\
\hline 4 & Bacillus cereus Frankland \& Frankland & $\mathrm{V}$ \\
\hline 5 & Bacillus subtilis Ehrenberg & $\mathrm{V}$ \\
\hline 6 & Clostridium botulinum van Ermengem & $\mathrm{V}$ \\
\hline 7 & Clostridium porogenes Metchnikoff & $\mathrm{V}$ \\
\hline 8 & Klebsiella pneumoniae Schroeter & V \\
\hline 9 & Staphylococcus aureus Rosenbach & V \\
\hline
\end{tabular}

Note: $V=$ Present. 
The correlation matrix obtained for the soil physiochemical and biological properties is presented in table 5. Positive and Negative correlations were observed in the soil properties. A negative strong correlation with a correlation coefficient of 0.71 was found between sand and silt content. Organic matter and clay had a very low correlation coefficient of 0.03 and 0.42 with silt content. The bacteria isolated in the study area with CFU of $10^{4}$ had a negative strong correlation coefficient of 0.81 with Nitrogen and a very weak negative relationship with magnesium (0.01). On the other hand, fungi isolated in the study area had a very weak correlation with Organic carbon and organic matter (0.01).

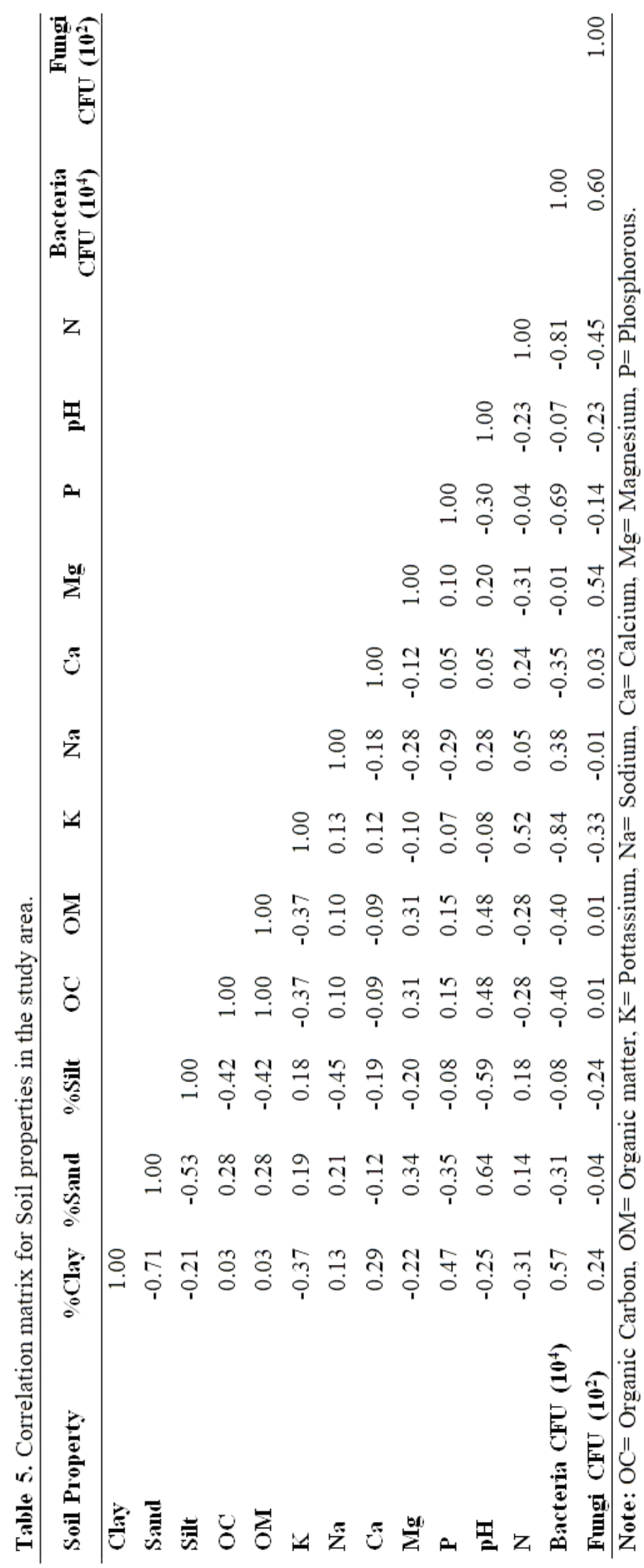




\section{DISCUSSION}

Rinta (2016) stated that the physicochemical properties of wood that are tree specific, such as the density, $\mathrm{pH}$, and water and $\mathrm{N}$ content, determine the composition of bacterial communities. The results of the soil $\mathrm{pH}$ obtained for the study area ranged from 5.69 to 6.66 ; this is expected as most soils in the tropics has their $\mathrm{pH}$ ranging from acidic to slightly neutral (Alloway \& Ayres 1997). Similar result was also reported by Oyedele et al. (2008). The low organic matter and other nutrients that were obtained in the study area could be attributed to the disturbance on the land during logging and logging activities. The forest ecosystem is a dynamic entity due to the activities of microbes which depend on varying environmental factors and various human activities (Buckley, 2003). Forest soils is a diverse microbial home on earth. Factors such as the prevailing weather condition at the time of soil sample collection, geographical location and species genetic makeup might have brought about low population in the occurrence of fungi and bacteria in this study. The total abundance and diversity of fungi and bacteria isolated in this work is below the number reported by Adeduntan (2009) and that of Adekunle et al. (2011), who obtained higher number of bacteria and fungi species (thirtythree and twenty-four respectively) in unthinned plantation stands in Akure forest reserve. The low number of fungi and bacteria obtained in the study area agrees with the work of Ford et al. (2004), who reported that reduction in soil biota could be as a result of any form of disturbance or change in the ecosystem that affects above ground vegetation.

The diversity and population of bacteria were more than that of fungi in this study area. This supports the assertion made by Alexander (1977) that bacteria are by far the most abundant group of soil microbes numerically. Most bacteria species that were isolated in the forest types are the aerobic spore formers especially the bacillus species which are able to survive adverse environmental conditions by producing extremely drought resistant endospores (Bigelow et al., 2004). The results of correlation regression analysis showed that low, moderate and strong relationships were found in the soil properties. This implies that increase in any of the properties will lead to increase in another.

\section{CONCLUSION AND RECOMMENDATIONS}

The results of the study revealed that continuous and excessive exploitation in the forest ecosystem could lead to loss of soil nutrients and reduced diversity and population of microbes. The roles of forest in climate mitigation and environmental conservation cannot be underestimated, when deforestation occurs, it has negative effects on the soil properties which invariably affect the soil microbes and the environment. Degraded forest should be protected to allow regeneration in order to enhance biodiversity conservation. Government should provide the appropriate resources needed by the forest policy maker to review and update obsolete laws. There should also be implementation of new laws at the same time ensuring proper monitoring and management of the existing forest from further anthropogenic activities.

\section{ACKNOWLEDGEMENTS}

I wish to thank Ondo state ministry of natural resources for permitting us to use the Park for this research and also appreciate those who helped during the data collection.

\section{REFERENCES}

Nannipieri P., Ascher J., Ceccherini M.T., Landi L., Pietramellara G. \& Renella G. (2003). Microbial diversity and soil functions. European Journal of Soil Science, 54: 655-670.

Rousk J., Demoling L., Bahr A. \& Baath E. (2008). Examining the fungal and bacterial niche overlap using selective inhibitors in soil. FEMS Microbiology Ecology, 63: 350-358.

Pietikainen J. (1999). Soil microbes in boreal forest humus after five. Finish forest Research Institute, pp. 78.

Sigstad E., Bajas A., Amoroso M. \& Garcia I. (2002). Effect of deforestation on soil microbial activity a worm-composite can improve quality? Thermo Chimicaacta, 394: 171-178.

Haddad N.M., Brudvig L.A., Clobert J., Davies K.F., Gonzalez A., Holt R.D., Lovejoy T.E., Sexton J.O., Austin M.P., Collins C.D., Cook W.M., Damschen E.I., Ewers R.M., Foster B.L. \& Jenkins C.N. (2015). Habitat fragmentation and its lasting impact on Earth's ecosystems. Science Advances, 1: Article ID: e1500052.

Adekunle V.A.J, Okunlola J.O. \& Oke D.O. (2011). Management of forest ecosystem for food security and rural livelihood in south west Nigeria. Final project report for 2011 START Grants for Global change research in Africa, 143 p.

Rinta (2016). Natural decay process affects the abundance and community structure of Bacteria and Archaea in Picea abies logs. FEMS Microbial Ecology 92: fiw087. [DOI:10.1093/femsec/fiw087]

Alloway B.J. \& Ayres D.C. (1997). Chemical principled of Environmental pollution. Blackie Academic and Proffesional, pp. 353359.

Oyedele D.J., Gasu M.B. \& Awotoye O.O. (2008). Changes in the soil properties and plant uptake of heavy metals on selected mucipal solid waste dump sites in Ile-ife, Nigeria. African Journal of Environmental Science and Technology, 3(5): 107-115.

Buckley D.H. (2003). Diversity and dynamics of microbial comminuties in soils from agro-ecosystems. Environmental Microbiology, 5(6): 441-452. 
Adeduntan S.A. (2009). Diversity and abundance of soil mesofauna and microbial population in South-Western Nigeria. African Journal of Plant Science, 3(9): 210-216.

Ford P.L., Potter D.U., Pendleton B., Ribbie W.A. \& Gottfried G.J. (2004). Southwestern Southwestern Grassland Ecology. In: Finch D.M. (Ed.) Assessment of Grassland Ecosystem Conditions in the Southwestern United States, Vol. 1. Gen. Tech. Rep. RMRSGTR-135-vol. 1. Fort Collins, CO: U.S. Department of Agriculture, Forest Service, Rocky Mountain Research Station, pp. 18-48. Alexander M. (1977). Introduction to Soil Microbiology, $2^{\text {nd }}$ Edition, New York, John Wiley and Sons, pp. 467.

Bigelow C.A., Bowman D.C. \& Wollum A.G. (2004). Characterization of soil microbial population dynamics in newly constructed sand-based root zones. Crop Science, 42: 1611-1614. 